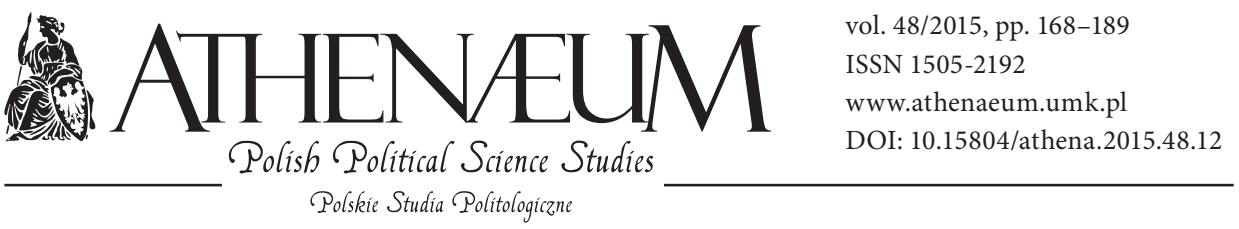

\title{
EUROPEANIZATION OF SLOVAK POLITICAL SYSTEM DURING THE ACCESSION PROCESS TO THE EUROPEAN UNION
}

\author{
Dušan Leška*
}

\begin{abstract}
Europeanization acted at all stages of society development in Slovakia, with varying degrees of intensity and in various forms, since the signing of the association agreement with the European Union. A significant impact was already in the stage of transition, when the consistent implementation of the Copenhagen criteria insist by the EC/EU help to return to the path of democratic development in Slovakia. However, it wasn't just about the application of the generally accepted principles of parliamentary democracy, but also on the active impact of the EC/EU institutions within the existing opportunities provided by the signing of the Association Agreement. A qualitatively new stage began after completion of the Copenhagen criteria and the opening of negotiations, which was to implement acquis communautaire into the internal legal order of the country. At this stage, clearly dominated the process of Europeanization “top-down", i.e. the adoption of standards, laws of the European Union, to make country compatible with other countries of the EU. After the entry of the Slovakia into the EU, a two-sided process of Europeanization: "up-down" and "bottom-up" has started.
\end{abstract}

\section{KEYWORDS -}

European Union, Europeanization, Slovak political system, transition, transformation

* University of ss. Cyril and Methodius in Trnava, Slovakia, Faculty of Social Sciences. 


\section{CONCEPTUALIZATION \\ OF THE ISSUE OF EUROPEANIZATION}

Europeanization is a relatively wide concept primarily standing for an approach to the study of mutual interactions between the European Union and a domestic political system. The term Europeanization is used in several contexts and refers to changes in individual member or candidate countries arising in the domestic economic and political system under the influence of the European Union. The term conditionality reflects this process from the point of view of the European Union; it describes the conditions required from the countries seeking to establish a closer relationship to the European Union or aspiring to become its member.

A specific form of an Europeanization issue was demonstrated in the relation with the countries of Central and Eastern Europe that overthrew their totalitarian regimes and expressed their interest to join the European Union. The countries were required to complete the transition, the process of establishing the grounds of parliamentarian pluralist democracy and market economy in order to be accepted to the community of free democratic countries associated in the European Union. As the state ownership of capital goods prevailed in these countries, privatization implying the establishment of market relations and market economy development was an important task to accomplish.

The European Union provided these countries with help from the very first steps towards democracy. However, a problem arose when the readiness of these countries to join the European Union was discussed. Several authors study the question whether the Europeanization was active since these countries' transition or whether it starts implying after they have joined the European Union. We believe that the conditionality of the European Union was, even if indirectly, influencing the countries since the early stages of the transition and had an immense impact on the form and formation of a political system, political parties system and, naturally, economic system. We attempt to demonstrate this fact following the analysis of the transformation process in Slovak society.

The research on Europeanization was mainly orientated on adapting institutions and the constitutional and legal framework to the rules and procedures resulting from the changing European environment (Brusis 2005: 27-28). It focused on the changes in domestic political institutions, processes and specific policies of the European countries in relation to the requirements of the EC/EU. Over the last two decades of research and generalisation of experience gained 
by the countries of Central and Eastern Europe, many valuable results have been achieved, particularly in the study of the impact of Europeanization on the political system of individual countries.

The term of Europeanization is closely related to the European integration process and to the way of how this complex process affects different spheres of policy in the countries associated with this process, or how far it affects framing the new European political structure. These processes can overlap to a certain degree and affect the policy at all levels. Perceived in this way, the research had been neglected for a long time and the study on national political systems was conducted separately from the research on the European integration (Fiala et al. 2009: 20).

This fact was emphasized in the work of S. Hix and K.H. Goetz who wrote: "For a long time, the importance of the European integration in the development of indigenous political systems appeared to be empirically negligible and therefore it was not categorized as a monitored element of research. At present, a significant scope of research has been revealed in which the change and continuity of domestic (national) political systems would become a determinant depending on the form, direction and speed of the European integration process" (Hix, Goetz 2000: 2).

The European integration consists of two mutually connected processes: on the one hand, political competences are delegated to the supranational level in order to obtain specific political results; on the other hand, a new structure of political institutions - including the executive, the legislative, and the judicial - at the European level is established. Delegating powers has the influence on the policy outcomes at the domestic level as well. These effects are visible, for example, in public administration where the European integration can lead to the introduction of a new style of work; to origination of the new relationship between the executive and the legislative power; to creation of new links between parties and voters or groups of voters which could affect individual parties as well as party systems.

Europeanization of policy can trigger a domestic change at three levels: a) institutional adaptation, b) changes in the structure of domestic opportunities (due to a new distribution of power and resources between domestic actors), c) change of the framework of expectations in the domestic policy. For this reason, the European Union policies can directly dictate a change in an institutional framework; they can also modify the institutional context of strategic interactions; or they can seek to change the institutional framework indirectly 
by influencing the beliefs and expectations of domestic actors, who align their strategy accordingly (Knill, Lehmkuhl 2002: 255-263).

The process of Europeanization can be controlled by the European Union or by domestic actors and can be induced by dual logic: the logic of appropriateness (actors are motivated by internalized identities, values and norms), or the logic of consequences (maximizing the power of actors acting rationally). Europeanization can arise only under the influence of external stimuli, i.e. conditionality corresponding to the dynamics initiated and controlled at the EU level. The European Union can set the conditions as well as rewards or penalties for domestic actors based on their adaptability. The second approach is represented by the model of social learning stemming from the logic of appropriateness. It is based on domestic elites identifying with the EU requirements and adopting the rules by their own will and according to the belief that they are legitimate and represent the most appropriate solutions to domestic problems (Schimmelfennig, Sedelmeier 2005: 8).

Europeanization conceived in this way is basically only one alternative of the transformation of political regimes in Central and Eastern Europe, i.e. the model of the so-called external transformation. Internal transformation is a process aiming at building a functional and consolidated democracy and market economy and, therefore, it is generated by internal motivation of society willing to implement the necessary reforms. This factor might not be a necessary condition of external transformation. During the accession negotiations with applying countries, internal transformation was gradually replaced with external transformation, i.e. with transformation required from outside the country with the aim of accommodating political, economic and legal environments of the candidate countries to the EU requirements. V. Hloušek and M. Pitrova claim that this transformation is not followed by a broad public discussion and is seen as a "technical" rather than "political" problem (Fiala et al. 2009: 103-104). This argument can be only partially accepted, because after the accession to the European Union, seeking compromises among domestic elites is necessary. Several authors consider the democratic transition of countries in Central Europe and Europeanization to be processes marked by many analogous features, sometimes the transition is directly or indirectly equated to this democratic consolidation (Ágh 2004; Kubicek 2003).

V. Hloušek does not agree with applying the concept of Europeanization to the phase of transition. According to him, it represents imitating the Western European patterns in shaping a democratic political system, but it is not an 
immediate response to the stimuli related to the development of the EC/EU (Hloušek 2004: 101-102). Therefore, he assumes that at the stage of transition we cannot talk about the processes of Europeanization or conditionality as these start after the transformation into the phase of consolidation. I do not perceive defining such strict borders to be adequate since these processes interrelate and as the experience in Slovakia indicates, Europeanization had occurred already during the period of transition. Based on the transitological paradigm, defining the stage of completing the transition and the shift to the stage of democracy consolidation is quite a difficult task. Frequently, the EU membership or proximity to the EU membership is provided as a criterion.

The EU influence on forming the democratic institutions in Slovakia can be divided into three stages. The first stage concerned fulfilling the political demands representing the elementary precondition to obtain an invitation to the opening accession negotiations to the European Union. The second stage covered the period of the accession process after signing the Treaty of Accession between the European Union and the Slovak Republic and it reflected approximating to the laws of the European Union. The third stage began after Slovakia joined the European Union and became a full member participating in shaping the policies of the European Union. Relations during the first two stages are asymmetrical, dominated by a direct vertical impact of Europeanization and conditionality (top-down), in the third stage, the process is bilateral, marked by mutual influencing (both top-down and bottom-up).

Europeanization could be responsible for creating a cleavage in the EU member states, dividing the parties into pro-European and anti-European. However, such cases are quite rare. As a rule, the concept of the attitude towards the European Union is, to a greater or lesser extent, reflected in the programme lines and policies of most relevant political parties. Nevertheless, this does not diminish the importance of investigating the impact of Europeanization on political parties. It is important to examine the indirect impact of Europeanization on individual political parties - on their programmes, structure, and practical policies. Simultaneously, two processes affect the functioning of political parties in European countries, both caused due to the process of European integration. "Firstly, the environment of national (domestic) political systems, which parties primarily exist in, is transformed; secondly, styles of policy making are modified" (Fiala, Hloušek, Suchý 2008: 49). Therefore, demands required from political parties in regard to promoting their political intentions were increased. 
The basic framework for studying the impact of Europeanization on political parties was proposed by R. Ladrech who allocated five areas of examining the impact of Europeanization on political parties. They are related to changes in the political programme, organisational changes, the formula of party competition, the relations between the parties and government, and the relations beyond the national party system (a new perspective of transnational cooperation between political parties) (Ladrech 2002: 396-400).

\section{THE ESTABLISHMENT OF INDEPENDENT SLOVAKIA}

The process of transition of the political system of Slovakia has began in the framework of the joint State, Czechoslovak Federal Republic, since the beginning of the 1990s. Part of democratic transition was also equal position for both Nations in a common State. Since the new political elites failed to find a mutually acceptable compromise, the Federation broke up and two separate States were created. The Slovak Republic also as an independent state came into existence on January $1^{\text {st }}, 1993$. The Constitution of the Slovak Republic was ratified, legislative and executive bodies were approved but many institutions were still missing. There came a complicated epoch of the division of the property common with the Czech Republic and creation of necessary state bodies and institutions. After the establishment of the independent state there appeared new tasks which were mutually multiplied and intertwined: it was necessary to build missing institutions of the state, a state apparatus, to apply for international acknowledgement and membership in international organizations, to create embassies, to meet international obligations and look for proper forms for further transformation of economy.

In accordance with the Constitution of the Slovak Republic, the law-making power was taken over by the National Council of the Slovak Republic, which assumed the competences of the Federal Assembly. The power of the government was given to the governments of the successor states and in Slovakia a new government was created after the election in 1992. The central institutions in the Czechoslovak Federative Republic were based in Prague, which was the capital of the federation, while in Slovakia there were only national bodies which were under the power of the federal bodies. After the split of the Czechoslovak Federal Republic, it was necessary to transform these institutions 
to have all the power and responsibility that concerned mainly the Ministry of Foreign Affairs, Ministry of Defence, Ministry of Interior Affairs, Justice, Foreign Trade, etc.

It was necessary to elect a president as the head of state. In accordance with the then valid constitution, the National Council elected the president of the republic upon the proposal of at least $8 \mathrm{MPs}$ while it was necessary to achieve 3/5 majority, i.e. 90 votes. In the second round of the presidential election, Michal Kovac won, nominated by LS-HZDS.

The fact that Slovakia was a successor state of the CSFR played an important role in the process of entering the international organizations, signing international agreements, and the acknowledgment of Slovakia by the world community. Despite it, Slovakia had to go through the whole procedure like a new state in the map of the world. It had to apply for the acknowledgment by other states, and it had to make diplomatic contacts, build embassies, and be accepted by international organizations.

A very positive signal was that the Slovak government proved the continuity of foreign policy of the CSFR focused on the participation in the Euro-Atlantic structures. At the beginning of 1993, Slovakia became a member of OSCE, the North Atlantic council for cooperation, which was a kind of preparation for entering NATO. On January $19^{\text {th }}, 1993$, United Nations accepted the Slovak Republic that completed its international legal approval. Based on the recommendation of the correspondents of the parliamentary assembly, it was accepted to the Council of Europe.

\section{EXCLUSION OF SLOVAKIA FROM THE PRE-ACCESSION NEGOTIATIONS WITH THE EU}

The most powerful political subject in this period was populist and authoritarian Movement for Democratic Slovakia (HZDS) led by charismatic personality V. Mečiar. After the election in 1994, HZDS created a coalition with the nationalistic Slovak National Party (SNS) and leftist subject, the Association of Slovak Workers (ZRS). The coalition usurped all political power in society, breached principles of parliamentary democracy, scandalized the opposition, infringed the rights of national minorities, in particular of the Hungarian minority, and infringed human rights. In economy, they asserted non-transparent privatization of State-owned enterprises to the persons close to the Government coalition. 
The political regime turned away from a path of democratic consolidation and departed towards the authoritarian regime.

After the establishment of independent Slovakia, the Mečiar's government promised that it would continue the foreign political orientation of the former Czechoslovakia and publicly declared its interest in the entry to the Euro-Atlantic structures, which was supported by people. On October $4^{\text {th }}, 1993$, the Slovak Republic signed an association agreement with the EU about joining, which the National Council ratified on December 15 ${ }^{\text {th }}, 1993$. In February 1994, in Brussels' seat of NATO, Mečiar signed a framework document about joining, the project Partnership for Peace.

An important condition for becoming a member of the EU was fulfilling the so-called Copenhagen criteria, which comprised the requirements in political, economic, and legal fields. To the political criteria belonged the necessity of the country to dispose of institutional stability as a guarantee of a democratic system and legal state, as well as to respect human rights and protect minorities. In the economic field, it was necessary to create a market economy, which would be able to compete with the pressure in the EU. The last condition was an acceptance of the communitarian law of the EU and the ability to implement it in practice. Reports about fulfilling these criteria were regularly sent to the EU and annually processed by the European Commission.

Breaching of democratic principles in the process of transformation was the weakest point not only of domestic but also of foreign policy of the Government of the SR. In its report about the progress of Slovakia, the European Commission expressed serious reproaches connected with the instability of the institutions and insufficiencies in democracy. On the basis of this evaluation, the European Council did not recommend to begin accession negotiations with Slovakia in Luxembourg in December 1997. Thus, the Slovak Republic was excluded from the group of 6 candidate countries, and it fell out from the first wave of enlargement of the EU. The relations between the EU and the SR were regulated by the individual Partnership for Entry, which was focused on those Copenhagen criteria in which Slovakia was weaker (Figel, Adamiš 2004: 10-11).

The next failure was the NATO summit in Madrid on July $8^{\text {th }}$, 1997 , where a decision that Slovakia would not be invited to entry negotiations to NATO was accepted. It was proved at the end of 1997 when NATO signed protocols with the new member states, the Czech Republic, Hungary, and Poland. Slovakia was missing because it did not fulfil the criteria mainly connected with democracy. 
In this phase, there was also a visible conflict line of the relations of political parties and the EU. Movement for Democratic Slovakia (HZDS) declared its interest to enter the EU, but it could not ensure it. It ignored the notices of the EU bodies and by its activities actually decelerated the entry to the EU. On the other hand, the opposition parties presented themselves as pro-European and argued that they could overcome the democratic deficit and ensure the entry to the EU. Before the election in 1998, the opposition concentrated mainly on this agenda. At that time, the idea of the entry to the EU had a big support of people of Slovakia and the worries about the failure were shared by 54 per cent of the population (Bútorová 1998: 168).

K. Henderson attributed the policy of rejecting the criticism of the European authorities by LS-HZDS in 1994-1998 to the "false Euro-optimism" that was a Slovak variant of Euroscepticism (Henderson 2005). On the contrary, all opposition parties presented their policy as pro-European, being able to overcome the deficit of democracy and ensure the Slovak access to the EU. Prior to the election held in 1998, the opposition based its reasons on the fact that it was able to manage Slovakia in the accession process. The fact played a key role in mobilizing Slovak voters.

The institutions of the EU used the strategy of traditional diplomacy through which they appealed to the government, other official institutions and pointed at insufficiencies and deformations. For this purpose, the opposition used also the Association Council and parliamentary committee. It showed the government by its attitude that the negotiations with the EU would not be open without removing the problems. However, the Government did not react. The second strategy was that the institutions of the EU addressed people and the opposition and supported non-governmental organizations, which mobilized the public. Their effort was focused on the preparation and performance of the election in 1998 (Malová, Láštic, Rybár 2005: 42).

The EU played an important role in overcoming the authoritarian tendencies and returning to the way of democratic transition. By excluding Slovakia from the group of the countries which were supposed to start the negotiations in Luxembourg in 1997, the EU clearly declared that either Slovakia removed deformations of democracy, or it would not become a member state of the Union. It had a decisive impact on public thought and activation of political powers, unification of all democratic powers which mobilized themselves and succeeded to oust LS-HZDS from the government and start renewing of democratic principles, international prestige of Slovakia, and a new period of negotiations with the EU. 
Europeanization was shown already before the signing of the accession agreements in the period of transition of society and it directed the transformation process in Slovakia and forming of political parties and a party system as well.

\section{THE RENEWAL OF DIALOGUE WITH THE EU}

Before the election of 1998, the Government of Mečiar has approved an amendment of the election, Act No. 187/1998 Coll., on the basis of which four election districts were cancelled and there was created only one whole state district within Slovakia with one list of 150 candidates. The amendment excluded the possibility of submitting a common candidate list for the coalition parties and it required 5 per cent of votes for each party of the coalition. As a consequence of this restriction, the creation of any coalitions before the election would be groundless. The created coalitions reacted to the situation in such a way that they registered as independent political parties. In this way, both Slovak Democratic Coalition (SDK) and Party of Hungary Coalition (SMK) were established. Among the opposition parties counted leftist Party of the Democratic Left (SDL) and right before election there was created a new political party - Party of Civic Understanding (SOP). Also in the election in 1998, the opposition parties' coalition created a broad coalition of SDK, SDL, SMK, and SOP, which gained 93 mandates in the National Council of the Slovak Republic and M. Dzurinda became Prime Minister.

The high representatives of the Union highly appreciated the democratic course of the parliamentary election and positive signals from Slovakia. The same evaluation was given to them also in NATO, in Brussels, as well as in Vienna, because Austria was the presidential country of the EU at that time.

The period after the parliamentary election in 1998 was a beginning of the new quality of relations and more intensive political dialogue between the SR and the EU. The priority of the new Slovak government and the Parliament was to achieve a positive recommendation of the Regular Report of the European Commission which reflected the state of fulfilling short and middle-term priorities of the Partnership for the entry. Therefore, the government focused on proper fulfilment of the Copenhagen criteria in domestic policy, which was the most criticized area.

The first step was a harmonization of the election law with the finding of the Constitutional Court, the amendment to the Constitution, and the approval 
of the presidential election in general election. In May 1999, the first general presidential election in Slovakia was held and thus, the 15 months period of the vacant presidential office was finished. The presidential election was a stabilizing factor of functioning of the political system. In July, the NC SR passed the law on the use of languages of national minorities in official communication, harmonizing the relevant legislative with the Constitution of the SR, international norms, and the recommendations of the OBSE, the Council of Europe, and the European Commission.

On December $3^{\text {rd }}, 1998$, the European Parliament passed the resolution to the candidacy of the SR for the entry to the EU in which it recommended a flexible approach to the SR. The EP recommended the Vienna summit to re-evaluate the situation after the September parliamentary election and to issue a new report about Slovakia as the situation in Slovakia had considerably changed after the election.

The Council of the EU approved the general position of the SR without comments. It was generally agreed that the SR would not claim exceptions from acquis communautaire within individual policies of the Union and would require only a limited number of temporary periods that came mainly from the need of increase of the effectiveness of Slovak economy. As for the fulfilling the economic criteria, it was necessary to say that restructuralization and privatization of banks and strengthening of financial discipline of the entrepreneur sector belonged to very important decisions. As for the domestic market, a law on technical requirements and the correspondence of products as well as a law on public procurement were accepted.

\section{ELIMINATION OF BACKWARDNESS AND OPENING THE PRE-ACCESSION NEGOTIATIONS}

Following the decision of the EC in Helsinki in December 1999, the SR together with five other candidate countries (Lithuania, Latvia, Malta, Bulgaria, and Romania) opened the negotiations about their entry at the introductory meeting of the Conference about the entry on February $15^{\text {th }}, 2000$. Here the SR presented a general negotiation position about the entry in which it submitted a realistic though an ambitious plan. Slovakia promised to harmonize its legislation with the EU law and create a relevant administrative capacity by the end of 2002. Slovakia chose January $1^{\text {st }}, 2004$ as a reference date for the acceptance and imple- 
mentation of acquis communautaire and this date was also considered a reference date of the entry of the Slovak Republic to the European Union (Figel', Adamiš 2004: 16).

At the beginning of the negotiations, the SR declared that it fully accepted the objectives of the Amsterdam Treaty defined in Article 2 of the Agreement about the EU and that it would be able to accept the acquis in the applied range in the time of the entry to the Union. It expressed its interest in the integration to the unified market of the Union and policies of the Community including joining the economic and currency union after the fulfilment of convergence criteria and the acceptance of common currency, the euro. The SR supported also the aims of the common foreign and security policy and expressed its interest to participate in the definition and formation of the European safety and defence policy. In the area of justice and domestic affairs, Slovakia expressed its interest in deepening cooperation in the borders control, in the field of asylum law and migration, as well as in the fight against organized crime, terrorism and drug smuggling already in the time of preparation for the membership (Figel, Adamiš 2004: 17).

The Slovak Republic did not plan to apply for alleviations from the implementation of the acquis communautaire. However, it required transitional periods in those fields where it was reasoned by the need of improving the effectiveness of Slovak economy or ensuring great capital investments. Such applications were not only reasoned but also justified by a realistic plan of inevitable steps for the achievement of harmonization with the acquis. The transitional periods concerned mainly the value added taxes and consumption taxes, protection of deposits, compensation schemes for the compensation of investors, provision of short term capital and operations with the tools of financial market. A sensitive issue within the domestic market was gaining of agricultural and forest land as well as domestic estates by non-residents. As the key fields to be negotiated, mainly the issues of the domestic market, transport, environment, energetic, agriculture, regional policy, and coordination of structure tools were considered.

In December 2000, at the summit in Nice, an important document of the EC for enlargement, the so-called road map which defined a schedule of priorities of the EU in negotiations with candidate countries during the further three chairmanships - Swedish, Belgian and Spanish, was accepted. The SR had an intention to enter the EU together with other countries of the Visegrad group and therefore, it laid stress mainly on priority chapters of the Swedish chairman- 
ship, i.e. the chapters of the domestic market (free movement of goods, free movement of people, free provision of services, free movement of capital) and on the chapters of the Law on Commercial Companies, the Environment and Social Policy and Employment.

The SR proved its negotiation potential as well as its real preconditions for the entry to the EU within the first wave of the enlargement in 2004. This fact was proved by the summit of the EU in Laeken (2001), which ranked Slovakia among 10 candidate countries which were supposed to enter the EU in 2004. In October 2002, the Regular Report of the European Commission was published. It evaluated the progress of the candidate countries in their membership preparation. The overall valuation of Slovakia was positive. The Commission recommended finalizing the accession negotiations with Slovakia by the end of 2002. The statement of the EC was approved also by the member states of the EU at a special session of the European Council in Brussels on October $24^{\text {th }}-25^{\text {th }}, 2002$.

The October summit of the EU in Brussels represented an important break in the negotiations with the EU because it created the preconditions for defining the substantive position of the EU in the issues of financial character. The session of the European Council allowed the new members to get direct payments, defined the amount and modalities and their use, as well as the total financial package were considered the most important outcomes. The total sum of the financial package was determined for structural activities, to the total sum of 23 billion euro for all ten candidate countries.

"Other important moments of the negotiations were the decisions of the member states accepted at the Council of 18 November 2002 which concerned the date of the entry of the new members which was appointed on 1 May 2004. From the point of view of Slovakia, it is decisive that the payments to the EU budget will be made from 1 May and our income from the EU budget will not be shortened, i.e. in 2004 we will gain (except for market tools in agriculture) financial means for the whole 2004" (Figel', Adamiš 2004: 26).

Together with harmonization of the Slovak legislation with that of the European Union, it was necessary to change the Constitution of the Slovak Republic as well. The government coalition had to ensure the constitutional majority (3/5) in the NC SR for the approval of the constitutional law No. 90/2001 Coll., by which the Constitution of the SR is changed and amended with the force from July $1^{\text {st }}, 2001$, and the original Article 7 of the Constitution was enlarged. An important change was represented by the new Section 2 of this Article, in which it is stated: "The Slovak Republic can, by the international treaty, which 
was ratified and promulgated by the law, or under this contract, transfer the exercise of its rights on the European Communities or the European Union. The legally binding acts of the European Communities and the European Union have precedence over the laws of the Slovak Republic. Accepting the legally binding acts which require implementation shall be made by the law or by the government regulation under Article 120, $\$ 2$ " (Constitution of the SR 2009). This article introduced the institute of the so-called delegated legislation to the Slovak legislature. Under this provision, the law No. 19/2002 Coll. was issued, specifying conditions of approximation orders of the Slovak Republic Government.

The relationships between the SR and the EU are regulated in the Accession Agreement. The agreement comprises legal conditions of the entry of Slovakia and other 9 accessing countries to the EU, it describes all exceptions, treaties and transitional periods on which the accessing countries agreed in their negotiations with the member countries of the EU.

The opening of accession negotiations, the implementation of all chapters of the communitarian law into the legal system of the Slovak Republic meant a new epoch of Europeanization of the economic and legal systems. In this case, it was a direct conditionality when the EU required real changes in the legal and economic systems without which it was not possible to enter the Union. Slovakia became compatible with the countries of the European Union in the field of economy and economic policies which enabled free movement of goods, people, services, and capital. Except for the compatibility with the member countries, these legislative incentives created optimal conditions for the development of market economy, free economic competition, and removal of any legal or technical barriers for trade exchange.

\section{ACCESSION OF SLOVAKIA TO THE EUROPEAN UNION}

Significant success of the ruling coalition was achieved in international relations and foreign policy, where the foundations were laid in the previous term. At the Prague Summit on November $21^{\text {st }}, 2002$, Slovakia received the official invitation to join NATO, and on March $12^{\text {th }}, 2004$, in Washington, Slovakia and six other countries of the former Eastern Bloc officially became members of the alliance.

At the same time, since Slovakia met all conditions for accession to the European Union, the EU Commission recommended all ten accession countries, 
among them Slovakia, with which negotiations were launched in Luxembourg. The Treaty of Accession was signed on April 16 ${ }^{\text {th }}, 2003$ in Athens by Rudolf Schuster, President of the SR, Prime Minister Mikuláš Dzurinda, the Foreign Minister Eduard Kukan, and Ján Figel, the Chief Negotiator for the SR accession to the EU. On May $16^{\text {th }}$ and $17^{\text {th }}, 2003$, a referendum was held in Slovakia on the accession of the Slovak Republic to the European Union with the following question: "Do you agree that the Slovak Republic becomes a member of the European Union?". The plebiscite was attended by $2,176,990$ people, which represented 52.15 per cent of all registered voters. 92.46 per cent of the voters expressed themselves for Slovakia's accession to the EU, 6.20 per cent were against. Thus the fact was confirmed that the vast majority of Slovak citizens support the accession to the European Union.

The National Council of the SR expressed its agreement with the Accession Treaty to the European Union on July $1^{\text {st }}, 2003$. The ratification documents were handed over to the Italian government on October $9^{\text {th }}, 2003$ to be preserved in the depositary of the Rome Treaties. Slovakia, along with nine other countries, became a member of the European Union as of May ${ }^{\text {st }}, 2004$.

The political and administrative structures of the Slovak Republic started to participate in the performance and development of common Union policies. Slovakia's political system became part of the political system of the European Union. It was necessary to create institutions providing necessary linking. Slovakia delegated their representatives to various bodies of the Union. The first Commissioner of the European Commission proposed by the Slovak side became the former chief negotiator, J. Figel. The Prime Minister became a member of the European Council and individual government ministers became members of various Minister Councils. In the general election, members of the European Parliament had to be elected, and Slovakia had 13 of them. MEPs are organized into parliamentary factions according to their political affiliation. Slovak political parties became members of the European parties.

The Permanent Representation of Slovakia to the EU (the so-called COREPER I and II) was created, further were developed the principles of representatives delegation to the Economic and Social Committee and the Committee of the Regions. Slovakia occupies several important positions in the committees and directorates of the European Commission. The Slovak representatives became an integral part of decision-making, supervisory, executive, judiciary and advisory bodies of the Union. The European Union played an important role in shaping and changing the nature of political institutions in Slovakia, it had a forming 
influence on the nature of the political regime in Slovakia. Through joining the European Union, the Slovak Republic gained many opportunities for fulfilling the public interest in internal politics as well as in all areas of foreign policy. Many important questions, orientated at the negotiating bodies of the Union, should be provisionally consulted by political parties which adopted a common position, and that is further promoted at the EU bodies. An important task was to develop an efficient and flexible mechanism of Slovakia's involvement in the EU policy-making and legislation. Considering the aim, a variety of provisions and government regulations were adopted, further were developed new coordinating bodies at the level of government, the ministries, and the National Council. Pursuant to law No. 253 of May 2005, the National Council set up the Committee for European Affairs, which is authorized to exercise its powers at considering and granting a mandate to the government during the EU negotiations. The Office of the Slovak Parliament created the Department for European Union Affairs and the Office of the Special Permanent Representative of the Slovak Parliament at the European Parliament and other EU institutions. Thus were created institutional conditions for regular and operational involvement of the National Council of the SR in policy-making processes in the country within the EU.

In December 2005, the Slovak government created the Ministerial Council of the Slovak Republic for EU Affairs that worked under the guidance of the Deputy Prime Minister for EU affairs. It became a coordinating, advisory, and expert body of the Slovak government for acting in the EU, and it coordinated activities of ministries and other central government bodies in EU issues. The Ministry of Foreign Affairs of the SR created a Section for European Affairs that participated in defining and implementation of current foreign policy objectives related to the EU and its member states. It actively cooperated with the Government Council for European Affairs, the National Council of the Slovak Republic, and other central government bodies. At the same time, the section organized and directed activities of the Permanent Representation of the Slovak Republic to the European Union and through subordinated territorial departments it governed activities of the embassies and consulates general in the states within the territorial scope.

The information system is an important element within the mechanism of cooperation in developing the Slovak opinions and proposals for legally binding acts and other acts of both the EC and the EU. The Government Office runs the information system of laws and legislative approximation and the Office of the 
National Council of the Slovak Republic organizes the tracking system of the Slovak Parliament legislative process following the system of European affairs.

Slovakia delegated the EU with a number of economic policy competences, which are its exclusive EU competence. The member states in these areas were granted the exclusive competence to adopt the binding EU legislation. The concept of exclusive EU competences is based on the assumption that the processes at the EU level are more effective than uncoordinated actions of the individual member states. It comprises the customs union, establishment of competition rules which are essential for the domestic market functioning, monetary policy for the member states with euro currency, keeping marine biological resources under the common fisheries policy, and common commercial policy.

\section{SLOVAK POLITICAL PARTIES IN EUROPEAN POLITICAL PARTIES}

The adoption of a political party into the European political parties increased its prestige and credibility, as reflected by the fact that it is accepted by the Association as a full member, that such a political party respected and applied in practice the values, standards and ideals of its political party's family. Therefore, all relevant Slovak political bodies sought entry to some of the European political parties. The adoption into the family of European political parties, once the necessary conditions had been fulfilled, was presented as a success and increase of the international prestige of the political party. This indirectly assisted the process of maturation and shaping of political parties in Slovakia, which is also a very important factor. It was then just a matter of political parties and their elites how to realise this potential and where to find a place in the political spectrum.

The first contacts with the European political parties, the first attempts to join these parties and to start an effective cooperation were made in the 1990s. The conservative and socialist parties were successful in this field. The KDH party with its leadership under J. Čarnogurský was the first party that became an observer in the European Democratic Union (EDU) in August 1990. When EDU merged with the European People's Party (EPP) in December 1996, KDH obtained the status of an observer in EPP. It did not request the status of an associate member for a long time, as it did not prove the federalist character of the Union promoted by EPP. The party of Hungarian Christian Democratic Movement (MKDH) became the observer in the EDU in September 1993. In 
1998, three political parties representing the Hungarian minority joined and formed SMK - the Party of Hungarian Coalition. SMK obtained the status of an observer in EPP in December 1999, and it gained the status of an associate member in June 2000.

SDK was created before the election to the National Council in 1998, when the original election coalition consisting of five political parties (KDH, DÚ, SDSS, SZS, and DS) was registered as a self-reliant political party, and thus a candidate in the election. Later, leader party M. Dzurinda created on the basis of SDK a new political party - the Slovak Democratic and Christian Union (SDKU-DS), which obtained the status of an observer in European People's Party in June 2002, and it became an associate member in May 2003.

HZDS attempted to communicate with left-wing parties, and later with conservative parties in the EU. Finally, it succeeded with liberal parties in 2009. Although the party declared its conservative nature and orientation that was reflected in the name of the people's party (LS-HZDS), in 2008 it succeeded in becoming an observer in the liberal Party of European Democrats (PED), forming a part of the faction of the Alliance of Liberals and Democrats for Europe (ALDE).

The SDL' party together with the Social-Democratic Party of Slovakia (SDSS) obtained the status of an observer in the European Socialist Party (PES) in 1995, and both parties became associate members in March1999. Since Smer became more and more popular and its preference was increasing, there was an option to integrate smaller left-wing parties with Smer. Before the election to the European Parliament in 2004, Smer had won support of its counterparts, left-wing parties active within the framework of the Party of European Socialists (PES).

Regular contacts between Slovak and European political parties played a key role in terms of cooperation from different points of view. The parties had their representatives in the bodies of the European political parties, participated in their assemblies and board meetings when EU issues and attitudes towards the accession countries were discussed. The parties had an opportunity to gain some experience and recommendations in terms of reforms and the most effective way of meeting the integration criteria. On the other hand, they had an opportunity to interpret and explain the situation in Slovakia and to win the support of European parties for their own political agenda. Mainly the factions or political clubs of the parties represented in the European Parliament could support or accelerate the pre-accession discussions that seemed to be very useful for Slovakia after 1998 (Leška 2015). 
It was the first election held in 2004, shortly after Slovakia had accessed the EU. That means that Slovak political parties did not have much time to get ready for elections of such a type and they did not have much experience in this area. The election was carried out pursuant to the proportional representation with a closing clause of five per cent. The campaign had been considered very dull and not impressive, and it had not managed to address the citizens and mobilise the voter support.

SDKÚ and KDH had three MEPs, SMK had two of them, the governing parties obtained totally 46.6 per cent of the valid votes and 8 MEP mandates. As for the opposition parties, both Smer-SD and LS-HZDS were successful and obtained three MEP seats, and the opposition obtained 33.9 per cent of the valid votes. All three successful coalition parties were members of the European People's Party - European Democracy (EPP-ED), and they became members of their political factions in European Parliament. The deputies of Smer-SD became members of the Party of European Socialists (PES). As LS-HZDS had not been successful in joining any of the European political parties, its three deputies did not belong to any party.

\section{CONCLUSION}

In conclusion, it can be stated that the Europeanization or Supposition acted at all stages of development of society in Slovakia, with varying degrees of intensity and in various forms, since the signing of the association agreement with the European Union. A significant impact was already in the stage of transition, when the consistent implementation of the Copenhagen criteria insist by the EC/EU help to return Slovakia to the path of democratic development. It helped to remove elements of the authoritarian regime in breach of the principles of parliamentary democracy, human and minority rights, the privatization of State property, and the establishment of transparent procedures to apply the market economy.

However, it was not just about the application of the generally accepted principles of parliamentary democracy, but also on the active impact of the EC/ EU institutions within the existing opportunities provided by the signing of the Association Agreement. (Pressure on the Government, the Parliament of the Slovak Republic in the framework of the Joint Parliament Committee; support for the democratic opposition and non-governmental sectors). Slovak political parties 
entering into the European political parties since 1990s, political cooperation on the level of EC/EU was launched, the effort to reconcile national interests with those of the EU. (It was the first form of institutionalization). At the same time, the creation of a free trade area launched the cooperation of Slovak companies with EU companies, as well as businesses which indirectly exert influence on the formation of the economics of the countries as part of the EC. Europeanization also meant preparing for the possibility of drawing from the pre-accession funds PHARE, SAPARD, ISPA, requiring the fulfilment of certain conditions, and the creation of new institutions through which the funds had been taken. So began the first institutional changes under the influence of Europeanization.

A qualitatively new stage began after completion of the Copenhagen criteria and the opening of negotiations, which was to implement acquis communautaire into the internal legal order of the country. It was the stage of the most intensive impact of the European Union, which is called supposition, the purpose of which is to incorporate legal, technical and other standards into the internal conditions of the country in order to become compliant with the European Union and in order to be able to participate as a full member of the EU after the entry into all areas of cooperation. Slovakia managed to realise this stage in a short period of two years, as the accession negotiations opened later, then with other countries. The Slovak Government and individual ministries played at this stage a key role, because they prepared the draft of laws and the National Council of the Slovak Republic, although its control function was applied, stayed a bit in the background.

This stage of "supposition" was a stage of the adoption of Community law and implementation of its legal, technical and tariff norms into the legal system of Slovakia. At this stage, clearly dominated the process of Europeanization "top-down", i.e. the adoption of standards, laws of the European Union, to make country compatible with the EU so it could enter without hindrance in all areas of cooperation. After joining the EU, it was necessary to amend the Constitution of the Slovak Republic, and to build up the institutional structure in Slovakia, as well as to build up the representation of Slovakia in the Brussels institutions, and to create mechanisms that would allow the country to participate in the formation of the EU policy decisions and implementation of common European policies. After the entry of the Slovakia into the EU, a two-sided process of Europeanization: "top-down" and "bottom-up" has started.

The important role played the Slovak political parties, which have begun to integrate into the European Political Parties since $1990^{\mathrm{s}}$ on the principle of 
partisan families and began close cooperation with them. They incorporated into their political programmes European issues, learned to combine national and European interests to work together within the framework of the European political parties and to formulate their attitudes towards European integration. The first elections to the European Parliament in Slovakia in 2004 were a test of their maturity and readiness to enter into the official policy of the EU, to get seats in the European Parliament.

\section{REFERENCES:}

Ágh A. (eds.) (2004). Europeanization and Regionalization: Hungary's Accession. Budapest: Hungarian Centre for Democracy Studies.

Brusis M. (2005). European Union Enlargement and the Europeanisation of Eastern Europe: Research Puzzles and Policy Issues. [in:] Patterns of Europeanisation in Central and Eastern Europe. Z. Mansfeldová, V. Sparschuh, A. Wenninger (eds.). Hamburg: Krämer.

Constitution of the Slovak Republic. (2009). [online:] www.nrsr.sk/web/Static/en-US/ NRSR/Dokumenty/constitution.doc; [accessed 25.05.2015].

Bútorová Z. (1998). Vývoj názorov verejnosti na vstup Slovenska do NATO. [in:] Slovensko $v$ šedej zóne? Rozširovanie NATO, zlyhania a perspektívy Slovenska. M. Bútora, F. Šebej (eds.). Bratislava: IVO.

Fiala P. et al. (2009). Evropeizace zájmů. Politické strany a zájmové skupiny v České republice. Brno: Munipress.

Fiala P., Hloušek V., Suchý P. (2008). Teorie a analýzy evropeizace politických stran a zájmových skupin. [in:] Evropeizace zájmů. Politické strany a zájmové skupiny $v$ České republice. P. Fiala et al. (eds.). Brno: Munipress.

Figel' J., Adamiš M. (2004). Slovensko na ceste do Európskej únie - Kapitoly a súvislosti. Bratislava: SSZP Centrum európskych štúdií.

Gyárfášová O. (2011). Voličské správanie na Slovensku. Teória, trendy, výskum. Bratislava: Renessans.

Henderson K. (2005). The Slovak Republic: Eurosceptics and Phoney Europhiles. [in:] The Party Politics of Euroscepticism. A. Szczerbiak, P. Taggart (eds.). Oxford: Oxford University Press.

Hix S., Goetz K.H. (2000). Introduction: European Integration and National Political Systems. "West European Politics" 23 (4).

Hloušek V. (2004). Proces europeanizace a politické strany $v$ kandidátských zemích. "Sociální studia" 1.

Knill Ch., Lehmkuhl D. (2002). The National Impact of European Union Regulatory Policy: Three Europeanization Mechanisms. "European Journal of Political Research" $41(2)$. 
Kubicek P. (eds.) (2003). The European Union and Democratization. London: Routledge London.

Ladrech R. (2002). Europeanization and Political Parties: Towards a Framework for Analysis. "Party Politics" 8 (4).

Láštic E. (2005). Referendum: absencia dohody o priamej demokracii. [in:] Spoločnost a politika na Slovensku. Cesty k stabilite 1989-2004. S. Szomolányi (ed.). Bratislava: Univerzita Komenského.

Leška D. (2011). Formovanie politického systému na Slovensku po roku 1989. Bratislava: Infopress.

Leška D. (2013). Politický systém Slovenskej republiky. Bratislava: Univerzita Komenského.

Leška D. (2015). The Europeanisation of Slovak Political Parties. "Slovak Journal of Political Science" 15 (1).

Malová D., Láštic E., Rybář M. (2005). Slovensko ako nový členský štát Európskej únie: Výzva z periférie? Bratislava: Friedrich Ebert Stiftung.

Radaelli C.M. (2003). The Europeanisation of Public Policy. [in:] The Politics of Europeanisation. K. Featherstone, C.M. Radaelli (eds.). Oxford: Oxford University Press.

Schimmelfennig F., Sedelmeier U. (eds.) (2005). The Europeanization of Central and Eastern Europe. London: Cornell University Press. 